\title{
Indonesian as the Language of ASEAN During the New Life Behavior Change 2021
}

\author{
Dian Eka Chandra Wardhana \\ Universitas Bengkulu \\ e-mail: dec.wardhana@unib.ac.id \\ Article History: Received on 13 January 2021, Revised on 20 January 2021, \\ Published on 23 January 2021
}

\begin{abstract}
Indonesian is studied and used as a language in ASEAN because Indonesian is the lingua franca. In WordPress posts, the Indonesian language ranks third after English and Spanish. However, the attitude of native Indonesian speakers is still negative, so the Indonesian language UN scores (30\% do not pass) are lower than the English national examination scores (only 5\% do not pass). The purpose of this research is to describe the tendency of using Indonesian in ASEAN. The research data is in the form of information about the use of Indonesian in ASEAN. The data were collected online from members of 5 (international) communities, such as MLI, KSLI (alumni), AMCCA, and lecturers who had assisted students during internships through SEA teachers, SEAMEO, and youth exchanges with partner universities. This research data analysis using the Delphi technique and inter-subjectivity test. The findings are based on the panelist reliability test with a value of 0.7441 greater than 0.70 , it is concluded that the model is consistent. Besides, the model reliability test was also carried out, and the result was that the value of $\mathrm{r} 11=0.874$ was greater than 0.70 , so the model was reliable. The tendency in the use of Indonesian in ASEAN carries native speakers of conditioning results (nurture nativism) with the tendency as mentioned above is valid and reliable.
\end{abstract}

Keywords: ASEAN, Indonesia, Internal Factors, External Factors, The Tendency

\section{A. Introduction}

Indonesian is a language that is easy, dynamic, unique, and always produces new words, either through creation or creativity or absorption from regional languages and foreign languages. The dynamics of the Indonesian language represents the speaker's way of thinking, and the number of Indonesian speakers is very significant (around 260 million or 10 languages in the world with the largest number of speakers) (langgeng Setyono, 2012), (dewara.com, -), and in 2020 the number of Indonesian speakers has reached around 300 million. Furthermore, one of the criteria for becoming the main language in the world is the number of speakers (Comri, 2009). The existence of this abundant number of speakers is followed by many global Indonesian language learning activities. This phenomenon has been seen since the 1980s. Indonesian is taught extensively from the continent of Australia to Europe, especially the Netherlands (CNN, 2020), and France (M.Ridwan, 2020).

Another fact revealed by the Indonesian Ambassador to Papua New Guinea (Nuigini, 2020), said that Indonesian is the second foreign language in Papua New Guinea. Even Indonesian in Papua New Guinea has become a Pidgin language (TV, 2020). Even on the Australian, 13 states make Indonesian the main foreign language (Bagus Ramadhan, 2016). This is proof that Indonesian is easy because Indonesian is the lingua franca (Steinhauer, 1994), (Sugono, Bahasa 
Volume 1 (3) 2020

E-ISSN: 2723-6919 P-ISSN:2746-0827

Indonesia Menuju Bahasa Internasional, 2017). Even in the Netherlands since the 1980s, the Indonesian language has been in demand by Dutch students, this happened until the 2000s, but due to political factors enthusiasts to learn Indonesian in the Netherlands decreased. On the other hand, another fact is very interesting, there has been an increase in Indonesian language users in East Asian countries, that is Japan, North Korea, and South Korea, Indonesian learners have greatly increased (Hyun, Vol 14, No 1). This is proof that Indonesian is very likely to become a global language. Even according to observations when carrying out the 2019 haj pilgrimage, Indonesian language users in Saudi Arabia and Egypt are very significant.

The various facts that have been written are external reinforcing facts about the condition of Indonesian as a global language and various business activities in several countries so that Indonesian can become a global language. These external facts are influenced by various other factors, such as economic, defense, political, and business factors carried out by the Government of the Republic of Indonesia through the Coaching and Language Development Agencies. This agency carries out various cultural missions by prioritizing Indonesian as an advocate for ideology, politic, economy, social, culture, defense, and security and has stood up the use of Indonesian in various spheres of state and other official forums through Presidential decree no 63 of 2019 (https:www.jogloabang.com/budaya/perpes-63-2019-penggunaanbahasa-indonesia) as a Presidential Decree which regulates the use of Indonesian in that area.

Besides, the actions of all Indonesian educational and cultural attaches in introducing Indonesian culture abroad have greatly helped to accelerate the recognition of Indonesian language and culture abroad. For example, the Dutch cultural attaché regularly hosts various Indonesian cultural performances in the Netherlands (TV C. , 2020), and in Australia, There is also a biennial conference on teaching Indonesian in Australia so that Indonesian language learning can develop better (Ramadhan, 2016). Furthermore, Papua New Guinea is doing the same thing (TV M. , 2020). The Indonesian language learning activity is managed by an institution called BIPA (Indonesian Language Learning for Foreign Speakers).

Based on research conducted by (langgeng Setyono M. I., 2012), (Sugono, Bahasa Indonesia Menuju Bahasa Internasional, 2017), Up to 2017, there are around 203 BIPA institutions spread across 48 countries. It is spread across Australia, ASEAN, Japan, Korea, Europe, and Saudi Arabia, and Egypt. In addition to organizing lessons with BIPA institutions, the government also provides scholarships. This scholarship provision is managed by the Dharmasiswa scholarship institution which is managed by the Jakarta Language Agency. Students who get this scholarship will learn the Indonesian language and culture in all corners of the country. For example, Bengkulu University received and carried out Dharmasiswa activities with students from Switzerland, Denmark, and the Netherlands, in 2010, and in the following year carried out mentoring activities from ASEAN students (Vietnam, Thailand, and Cambodia) to Bengkulu and FKIP University students. Bengkulu to ASEAN through the Seameo and SEA Teacher programs as well as youth exchange programs conducted by UPT KSLI with partner universities in ASEAN (Yansen, 2019). The scholarship program continues and is developed by the Bengkulu University FKIP English Language Education Postgraduate Program by involving 3 students from Vietnam.

Based on the writer's observations during 2016-2020, there are several state universities and private universities that provide scholarships to global citizens who are interested in learning the Indonesian language and culture. For example, State University of Malang, Mochmamadyah University Malang, Sebelas Maret University Surakarta, University of North 
Sumatra Medan. This is additional evidence that there are efforts to turn Indonesian into a world language. This scholarship provision encourages world citizens to learn the Indonesian language and culture even though during the pandemic (2020) learning activities online. There may be still some state universities and private universities that I do not know as scholarship providers to world citizens. Furthermore, other government efforts to internationalize or turn Indonesian into a world language, which is utilizing exchange programs between Indonesian students and other countries, the existence of scholarships to study abroad provided by the government to outstanding students, and language ambassador programs, and the existence of Indonesian language teachers who are abroad. All of these programs create a language exchange that makes many foreign countries understand Indonesian. This activity in 2020 will receive full support from the only independent learning program on an independent campus from the Ministry of Education and Culture (Indonesia, 2020).

Another fact that is developing from Indonesian to a global language is the holding of regular broadcasts in Indonesian by the BBC (London), Radio Australia, VoA (America) (Suprianyanto, 2016). These various conditionings are based on observations over the last 5 years that have shifted the national culture to the ASEAN regional culture (one example, the market. In the past, markets were a place to interact, as well as transact, now the goods on the market cannot be negotiated, so the market is no longer a place to interact). Besides that, the more contemporary, individual cultures that are developing, the culture of typical Indonesian groups are gone. This contributes to the use of Indonesian in international languages (Sugono, 2017) because language denotes the nation. Besides this, the internal conditions of the Indonesian language with a unique and easy linguistic system make Indonesian easy to learn. This uniqueness is seen from the development of entries in the online Indonesia Dictionary (around 100,000 entries and 4100,000 glossaries in various fields of exacta, humanities, and education) (Sugono, Bahasa Indonesia Menuju Bahasa Internasional, 2017), is a forerunner that cannot be underestimated. Coupled with the condition of the Indonesian language which is used as a social language in Indonesia and Malaysia, and strengthened by various institutionalized discussion areas between Indonesia, Malaysia and Brunei (MABBIM) and an established writing system contained in General Guidelines for Indonesian Spelling, and Indonesian Language Grammar Guidelines, as well as Indonesian Language Proficiency Test.

Also, Indonesian is verbally used by its users in various applications (WA, Telegram, Twitter, Linked In, Instagram, and various other applications), this is a sign that Indonesian can be used as social interaction in the millennial era (Purwo, 2020). Furthermore, even this language sociolinguistically has the experience of uniting 746 regional languages and is highly respected by its users (Indonesia P.-P., 1928). So there is no doubt that Indonesian has the potential as an international language.

Based on this phenomenon, how is the tendency of Indonesian in ASEAN? Given that ASEAN is a neighboring country to Indonesia with 10 countries in the community. ASEAN is the first step in the spread and manifestation of Indonesian in the international world?

\section{B. Methods}

The research method used to describe this tendency is a mixed method of descriptive qualitative and quantitative with the Delphi-inter-subjectivity technique. This is done to describe the tendency of Indonesian as an ASEAN language in a period of changing new life behavior. The research data is in the form of information about various theoretical and practical facts about 
Volume 1 (3) 2020

E-ISSN: 2723-6919 P-ISSN:2746-0827

the use of Indonesian. Data collection techniques used written instruments and data developed in the mass media. Also, to support the validity of the data, research data was "taken" from interviews conducted by Kompas TV and Metro TV, when interviewing the phenomenon of the tendency of the Indonesian language in the Netherlands and Papua New Guinea.

The instrument that has been formulated consists of 20 questions distributed in 7 communities, namely MLI, ASFLI, HISIKOM Malang Commissariat, LPPM Bengkulu University, AMCA community (UMM-International with 7 countries). It should be noted that these five communities consist of a collection of various researchers who have had cross-cutting experiences in ASEAN. Four (4) LPPM members who are members of the WhatsApp group LPPM Bengkulu University are managers of student exchange cooperation during internships between countries in ASEAN, either through a collaborative program with SEAMEO or SEA Teacher. The LPPM community that is targeted to participate in filling in this instrument is the Deputy Dean 3 of FKIP University of Bengkulu, Deputy Chancellor 3, Dean of FKIP, and UPT KSLI at Bengkulu University. Besides, the data collection instrument was filled by lecturers (3 lecturers of Indonesian Language Education), who had assisted interns to Cambodia, Vietnam, and Thailand. Thus, this instrument is distributed to personal (7 people) who have competence in this field and 2 public officials.

The data collection instrument contains 20 questions that represent various phenomena of tendencies in the use of Indonesian in ASEAN. The representation of the intended tendencies is formulated based on the documents that have been collected in the form of the results of interviews filtered through social media, textbooks, published articles, and the phenomenon of interviews with 5 respondents who have the requirements to see this tendency. Before the instrument is filled in, validation activities are carried out, so that the instrument becomes a valid and reliable instrument. Instrument validation was carried out to 5 professors who were also scattered in the community. Interviewing activities of Indonesian language users in ASEAN are used to support the description results through quantitative tests with the Delphi technique and inter-subjectivity tests.

\section{Results and Discussion}

The results of research on the tendency of Indonesian in ASEAN begin with a narrative that until now (2021) Indonesian has great power to become the world's language, international language, and language in international forums. Malay language expert, James Collin in 'Bahasa MELAYU, World Language: A Brief History (2011), estimates that the speakers of Malay who are the forerunners of Indonesian in 2020 are estimated to be around 300 million. Before the proclamation of independence, Indonesian was "crowned" as the language of unity on October 28, 1928, and was held in high esteem by its users. This is supported by several important events that strengthen Indonesian as a valid and reliable language to be used in ASEAN. Even Bambang Kaswanti Purwo, Professor of Linguistics (Purwo, Penelitian di Era Mileneal, 2020) emphasized that Indonesian is currently third after Spanish in WordPress posts and is designated as the second official language in Vietnam. This fact was reinforced by the Indonesian Ministry of Foreign Affairs (Diplomacy, No. 106) that at least 52 foreign countries opened the Indonesian Language Program (Indonesian Language Studies).

Subsequent milestones are evidence of the calculated tendencies by the Delphi technique and the inter-subjectivity tests performed on the data. The analysis results show that based on the panelist reliability test with a value of 0.7441 greater than 0.70 , it is concluded that the tendency 
Volume 1 (3) 2020

E-ISSN: 2723-6919 P-ISSN:2746-0827

model is consistent (reliable). Besides, a model reliability test was also carried out, and the result was that the value of $\mathrm{r} 11=0.874$ was greater than 0.70 , so the model for the tendency of Indonesian as a language in ASEAN is reliable. Thus the Delphi technique used to analyze the data shows the rationality that the Indonesian language with a simple, easy and unique model can occupy and function the Indonesian language in the interplay of the world of the life of the Indonesian people during interactions between nations, especially in ASEAN.

Indonesian has proven itself to be used to convey complex thoughts in science in a clear, orderly, and precise manner. Indonesian is a cultural feature of the Indonesian nation that can be relied on during interactions between nations in the era of globalization, both in official and informal forums. This can be proven by the large number of BIPA learning institutions in various countries in ASEAN. We can see the evidence about this quantitatively on the following map.

Table 1: Quantitative map of language institutions (Indonesian) in ASEAN countries (adopted from https:/bipa.kemendikbud.go.id)

\begin{tabular}{|l|l|l|l|}
\hline No. & Country & Linguistic Institution & Total \\
\hline 1. & Filipina & & 24 \\
\hline 2. & Vietnam & & 4 \\
\hline 3. & Indonesia & & 67 \\
\hline 4. & Laos & & 2 \\
\hline 5. & Myanmar & & 3 \\
\hline 6. & Timor Leste & & 29 \\
\hline 7. & Malaysia & & 6 \\
\hline 8. & Kamboja & & 11 \\
\hline 9. & Singapura & & 12 \\
\hline 10. & Thailand & 43 \\
\hline
\end{tabular}

Table 1 can tell that the conditions for BIPA learning in ASEAN can illustrate that Indonesian has the opportunity to become an international language. This condition represents the number of learners who are learning Indonesian. The Ministry of Education and Culture's Language Agency has noted that there are around 47,511 Indonesian learners in ASEAN and around 116 BIPA learning institutions in ASEAN. A very abundant amount. In addition to this, Indonesia has the fifth largest native speaker in the world. Indonesian is the largest language in ASEAN with 4,463,950 people and is the most popular language in Australia. Certainly, this shows the efforts made by the government to internationalize the Indonesian language following the mandate of Article 44 of the Republic of Indonesia Law No.24 of 2009 concerning the Flag, Language, and National Symbols and the National Anthem have achieved significant success.

Meanwhile, the BIPA Program has expanded throughout the world, there are 219 educational institutions both at home and abroad that conduct BIPA teaching (Liliana Muliastuti, Chair of the BIPA Teaching and Activist Affiliation. Apart from the BIPA program, there is also the Darmasiswa program. It is the provision of scholarships for foreign students who are studying culture in Indonesia. Various valid and reliable Indonesian language development programs with this phenomenon are also supported by follow-up programs both carried out by the Language Agency and by government agencies. Since the 1980s the Center for Language 
Development and Development, an institution that carries the 1945 Constitution article 36 paragraphs 2 and 3, and this institution changed its name (since the 1990s) to the Language Agency (in central / Jakarta), meanwhile, in the regions, this institution was given the name Balai Bahasa or the Language office, the Language Agency organizes major events every five years, by inviting various linguistic experts to discuss and find solutions to various language problems every 5 years (Bahasa, 2018). This is the implementation of Law no. 24 of 2009 article 44 so that the Language Agency and the language office directly have the main task of maintaining the sovereignty of the country by prioritizing Indonesian, preserving local languages, and mastering foreign languages.

The implementation of Law No. 24 of 29 was also welcomed by higher education academics by formulating a series of programs. The programs in question are; (1) Programs championed by hundreds of professors who are members of the professor forum (BaBe, 2020), voicing the use of Indonesian in international conference forums, so that there are (some) forums that organize it in Indonesian. (2) Program for the emergence of new journals by the research community led by Prof. Handoyo Puji Widodo, that is a reputable international journal that uses Indonesian as the language of introduction, namely the International Students Agency And Identity (JIS) Journal, a journal with the theme of writing various student problems in the world and its problems and solutions. This journal is the first published (in Indonesian) in October 2020 (Widodo, 2020) and is a reputable international journal published in Indonesian.

The next program is; (4) a program initiated by SEAMEO and SEA Teacher as well as a youth exchange program conducted by UPT KSLI with partner universities in ASEAN (Yansen, 2019). These programs exist in all State Universities and Private Universities in Indonesia and are managed by the UPT KSLI which is coordinated by the Vice-Chancellor in the field of cooperation. (5) Programs developed by the Postgraduate English Language Education Program and the Indonesian Language Education Postgraduate Program, for example, the Postgraduate English Language Education Program FKIP Bengkulu University involving 3 students from Vietnam.

In a global context, these programs can be used as a means of cultural diplomacy. Language as part of the culture is no less important for cooperation between countries for the national interest. With its rich language, Indonesia can carry out cultural diplomacy to attract many foreign tourists and foreign investors. In addition, to reflect the positive image of Indonesia in the international world, and the Indonesian language as the guardian of the Indonesian nation and State (Mayani, Peluang Pengajaran BIPA, 2020). The development of BIPA learning in ASEAN cannot be separated from historical nuances. History says that the development of the Indonesian language was initiated from the forerunner of the trading languages that developed from Malay in ASEAN (Rambu, 2016), and the forerunner of the Indonesian language was initiated by the foresight of Indonesian youth in 1928. Indonesian youth in that year took an oath that Indonesian was upheld as the language of the unity of the Indonesian nation.

These various external facts are also balanced with internal facts that develop in the country. KBBI (online), for example, notes that vocabulary and terms in various domains when Indonesian are used as an advocate for knowledge and a means of daily communication have experienced rapid development. The development of vocabulary and terms at KBBI is extraordinary. Indonesian vocabulary and terms have been very globalized, even this vocabulary developed from the local vocabulary used by millennial speakers. An example of "santui" malam (one of the trans TV shows comes from Sundanese, a regional language that 
has become globalized), lambe KISS (one of the awards programmed by Indosiar), from Jogya there is the language $D A G A D U=$ your eyes, from Malang there are languages that are reversed from left to right, for example, saya=ayas, nakam=makan, nawak=kawan, libom=mobil, kadit kane=tidak enak, holokes = sekolah, uluc=lucu, uslalu = selalu, tahes=sehat, ambyar (javanesse), the languages that are in Wordpress posts, for example, Santuy malam, kepo, hbd, SUT, sll, kece badai, informasi sunami, palbis, cabut dulu, cukstaw, anjirr, Garing (not funny/interesting), santuy (don't hurry), rekues (request), kece (catchy), nolep (no life/don't care about the environment), lappi (laptop), udah taken (someone already has), chek it out, kudet (not up to date), ilfil (lose interest/felling for someone), jaim (guard/protect one's image) (Purwo, Penelitian Linguistik Mileneal, 2020). This phenomenon explains that Indonesian vocabulary as a means of thinking of the Indonesian nation has been firmly grounded in the local sphere to be able to be used as a means of communication in the global realm.

Vice versa, even global vocabulary can be absorbed by Indonesian vocabulary. For example, during a pandemic, dozens of words have been successfully "entered" into Indonesian vocabulary. For example, the vocabulary of corona (coronavirus covid 19), lockdown, social distancing, physical distancing, rapid test, swab test, coronavirus (covid-19), hand sanitizer, droplets, local transmission, imported cases, herd immunity, and new normal (University, 2020). The vocabulary is growing along with the dynamic life of the Indonesian-speaking community because language is a tool for thinking. In recent developments, even the words related to corona and the prevention of corona transmission, for example, those related to implementing health protocols have been translated into 77 regional languages. (balaibahasadiy.kemendikbud.go.id, 2020).

This fact indicates that the translation of foreign vocabulary into Indonesian as well as foreign languages or Indonesian into regional languages can be done by Indonesian. The phenomenon of translating foreign vocabulary (new normal behavior) has been successfully translated into 77 regional languages. It is important to socialize terms during the new normalcy in a language familiar to the local community so that they are able to follow the development of new life patterns that are developing in the world so that they can avoid pandemic diseases. (Badan Pengembangan dan Pembinaan Bahasa, 2020). The vocabulary that is meant in this new normal era (September-December 2020) is the names of masks as one of the personal protective equipment (PPE) that is highly recommended by the government in breaking the chain of transmission of covid 19. These words are for example scuba masks and have not been translated until now, this is because people are very creative in creating masks. The dynamics of Indonesian vocabulary during 2020 is the development of vocabulary that is influenced by English because English is a working language (Mayani, 2020).

Besides this, the phenomenon of the life of the Indonesian people at this time is influenced by the nuances of the pandemic, and the atmosphere of community life today is a global atmosphere and the era that is happening today uses the millennial language/internet language. (Purwo, 2020). Analogically, if global life is shrouded in a pandemic atmosphere, social life and Indonesian language will be covered in the vocabulary of pandemic life. This is a sign that language competence in Indonesian society is used as a means of thinking (Chomsky, 2006, pp. 8-9), besides language as a representation of grammatical competence (syntax), and language acquisition. Thus the competence of the Indonesian language follows the flow of thinking of Indonesian society which is also global (Dahlan, 2000). 
The dynamic development of Indonesian vocabulary marks the nuances of people's thinking because language shows the nation and the development of people's thinking power is represented in the language of the community (Malsasa, 2012), (Wardhana, 2018). The current development of Indonesian has great power to become a world language, an international language, the language used in international forums (Bahtiar, 2020), and based on the results of observations during 2018-2020, even this language is used in informal interaction activities, for example, when in the cities of Mecca and Medina during the haj pilgrimage. Officials at airports, mosques, and when shopping at markets and malls, are used in Indonesian. Even when people from abroad playing Tik-Tok use the Indonesian language a lot, or when we are in Paris, some sing dangdut songs (Ridwan, 2020). In addition to this, there are many phenomena of foreigners walking along the streets of tourist attractions (Jogja, Bali, Malang, Semarang) using Indonesian when interacting and making transactions with Indonesian citizens.

The dynamics of fast-flowing change, advances in communication, and information technology have brought Indonesian identity to the global world. This dynamic leads to increasingly visible language homogeneity. This can be proven by the names of various types of businesses, such as names of shops, companies, housing complexes, and so on. This change must be addressed wisely so that the development of the Indonesian language is in accordance with Indonesian cultural identity and language. As emphasized by Dahlan (2000: 131), that education must be able to build a proud identity in the Indonesian language and thus pride as a nation. Ridwan (2000: 145) believed that the Indonesian language will be able to fill the requirements and be ready to face the various challenges of an increasingly advanced era of science and technology. Judging from the very simple structure and reading of Indonesian, Indonesian is an easy language to learn. A proof that can believe that in the future Indonesian can become the language of world civilization, quite a lot of countries in the world have studied Indonesian.

Other evidence and facts that the Indonesian language has globalized is that there are many scientific works in the language of the nation's children who have enlivened the globalization of science in the field of language (Sudaryanto, 2017), (Arka, 2020), (Arka, The Language Documentation Quartet, 2020), (bahtiar, 2020), (Baayen, 19th November 2020), (Crosthwaite, 2020), (RAJEG, 2020), and the recognition of Pantun as an intangible heritage by UNESCO from Indonesia and Malaysia (Antaranews.com, 2020), and Jurnal International Students Agency And Identity (JIS). This journal is a Scopus indexed journal using Indonesian as the language of instruction. Apart from this, several facts strengthen Indonesian as a global language in Southeast Asia. The facts that are meant are; (1) Geographically, Indonesia is the biggest country of the ten countries in ASEAN (around 1,904,569), while the smallest is Singapore, 660 square kilometers (https://www.kompas.com/skola/read/2020/01/12, 2020). (2) Indonesia's military strength in ASEAN has an index with a Power Index (PI) of 0.2804, and it is ranked 15/137 countries and is ranked No.1 in ASEAN (://www.liputan6.com/global, 31 Maret 2020), (3) Teaching BIPA in Vietnam starting February 15, 2019, Indonesian began to be taught as a subject in the Oriental Studies program at the University of Social Sciences and Humanities, Vietnam National University (USSH VNU, Hanoi, in Hanoi Indonesian is taught in 3 levels, that is level A1, A2 and A3, Teaching Indonesian in Hanoi was opened for the first time in 2 places, that is the Indonesian Promotion Umah Indo-Center in Hanoi and Hanoi University, as well as the fact in Vietnam that there is a certain motivation to learn Indonesian including to work, marry and trade in Indonesia.

Thus Indonesian is the second foreign language spoken in Vietnam, (4) Various ideological struggles that have been carried out in ASEAN are; (a) in 2011 Indonesia became chair of 
Volume 1 (3) 2020

E-ISSN: 2723-6919 P-ISSN:2746-0827

ASEAN, and Indonesian was planned as ASEAN language, (b) The Indonesia-Malaya Roundtable Conference forum, July 25-26, 2011 in Kuala Lumpur, recommended the use of Indonesian-Malayan as the official language within the Association of Nations in ASEAN, (c) The Deputy Speaker of the Indonesian House of Representatives at that time, Priyo Budi Santoso, at the meeting of ASEAN countries on September 25, 2011, stated that the Indonesian delegation was fully committed to proposing Indonesian as the language in ASEAN, but was rejected by the Philippines because they used English and Tagalog and only $5 \%$ of the population of the Philippines who speak Indonesian. However, the discourse of Indonesian in ASEAN was not a priority for discussion at the 18th and 19th ASEAN Summits on 17-19 November 2011 (Mayani, Peluang Pengajaran BIPA, 2020).

The next fact is a fact (5) that Indonesia is the third official language of ASEAN after English and Burmese. The current linguistic conditions in ASEAN are English, Burmese, Indonesian, Filipino, Khmer, Laotian, Malay, Mandarin, Tamil, Thai, and Vietnamese. (6) Currently developing statistical data shows that Indonesian has the fifth largest native speaker in the world, totaling around 269.6 million people (.tempo.co/read/1307583/bps-proyeksi-jumlahpenduduk-indonesia-319-juta-jiwa-pada-2045/full\&view=ok, 2020). Meanwhile, the number of people who have migrated abroad is 4,463,950 people (Bahtiar, Bahasa Indonesia, (Menjadi) Bahasa Dunia, 2020). (7) The potential economic power of Indonesia is the third strongest after China and India, and the 16th largest in the world, which is a member of the G20. (8) Peremnaker No. 12/2013 on Procedures for the Use of Foreign Workers requires that Foreign Workers be able to speak Indonesian, but this requirement is abolished in Permennaker No. 16 of 2015, article 26 Permennaker No. 12/2013 "Foreign workers who are employed by the employer are required to communicate in Indonesian". Article 26, Regulation of the President of the Republic of Indonesia Number 20 of 2018 concerning the Use of Foreign Workers, every employer of Foreign Workers is obliged; (a) appoint Indonesian workers as companion workers; (b) carry out education and training for Indonesian workers in accordance with the qualifications of the position supported by foreign workers, and facilitate education and training in Indonesian for foreign workers. Particularly for fact number 8, there are conflicting regulations in effect in Indonesia, so it is confusing and very grateful that hopefully what applies is the latest regulation, namely article 26 of the Presidential Decree No. 20 of 2018, however, the government needs to be consistent in implementing the latest Presidential Decree on Government support for Indonesian so that it tends to become a global language in ASEAN, and the world is supported by Presidential Decree No. 63 of 2019.

The facts that have been discussed are internal language and facts outside the "language". Furthermore, the facts about the language developed in Indonesia besides the fact that Indonesian is used as a thinking tool, represented in the development of terms that affect vocabulary and terms are (1) Indonesian Online Dictionary, (2) Indonesian Grammar Guidelines, according to Chomsky's opinion (Chomsky, Language and Mind, 2006), that the clutter of thinking of a people can be represented in grammar, language acquisition, and thought. Thus, the existence of the Indonesian Language Grammar Guidelines is very significant. (3) Indonesian Spelling which is very popular with the General Guidelines for Indonesian Spelling regulates written rules for writing letters, punctuation marks, vocabulary, and terms. (4) Indonesian Language Competency Test for Foreign Speakers (UKBI), is a proficiency in the Indonesian language, which at the beginning of the preparation of the language test was intended for foreign speakers or foreign workers who would earn a fortune in Indonesia. However, in its development up to 2020, UKBI is intended for various purposes, for example for civil servant examinations, Indonesian language proficiency tests for students, 
language proficiency tests for teachers and civil servants who will be promoted, and various other official needs.

The fact of an established language is supported by Park Jae Hyun (Department of MalayIndonesian Language, Hankuk University of Foreign Studies, South Korea. Download 2020 Dec 6. Potential and Challenges of Indonesian Language Towards an International Language. The government has steps to globalize the Indonesian language by doing Improving grammar and making software to learn Indonesian for foreign speakers. (page 12) Added by Park Jae Hyun, that making grammar software needs to be equipped with word formation guidelines if necessary there is a table so that when foreigners form certain basic words, have a certain clarity of meaning (with the criteria for forming customary Indonesian words). For instance, "tertawa" when added with ter-, $-i$, ter-kan also $d i$ - and $-i$, has a clear meaning so as not to confuse foreigners who are learning Indonesian, but it seems that his ideals need to be added that the formation of words in Indonesian also takes into account the pragmatic side.

This condition is important in order to give an idea to foreigners who are learning Indonesian, that there is the use of affixes (Indonesian customs) so that foreigners have guidelines for forming affixes. Cipatakan software that can correct writing automatically, for example, what we can see on a computer device when we type the wrong words/vocabulary, will automatically be corrected by the computer. Thus there is an impression that Indonesian is an easy and simple language so that it is easy to learn.

Empowerment of Indonesian is still a serious test of Indonesian language proficiency for both native and foreign speakers, but there are still many government institutions that violate it for reasons of accelerating development and this condition has no doubt, so the existence of Presidential Decree No. 63 of 2019 seems barren. Whereas in various foreign countries that teach Indonesian to foreigners (for example in South Korea there are 10 private institutions that teach Indonesian via the internet). Adhere to the Grammar Principles $=$ there is already a book on Indonesian Language Standard Grammar (first edition published in 1998), and Indonesian Lentera 1-3 (first edition by the central BIPA team in 2008).

In a global context, this development can be used as a means of cultural diplomacy, because language as part of the culture is no less important for cooperation between countries for national interests. This language, which is a gift from Allah, can be used to carry out cultural diplomacy, and to attract foreign tourists and foreign investors to Indonesia. However, the interest of these foreigners is not matched by the good attitude of the Indonesian people towards the language. Bambang Kaswanti Purwo (Purwo, Penelitian Linguistik di Era Mileneal, 2020), explained that Indonesian is no longer controlled by some of today's Indonesian children. They began to turn to be speakers who are more fluent in foreign languages (English) than Indonesian itself, a peculiarity that is second to none in the world.

This is supported by the fact, that the score of the English National Examination is higher than the value of Indonesian. The bilingual style used to be a very popular language style among teenagers. Even Remy Silado (teen novelist) considers that this phenomenon is considered a natural symptom due to the absence of a character among teenagers. This phenomenon in French is referred to as a symptom of a nature: juvenile delenguante. This phenomenon illustrates the phenomenon of cultural helplessness towards a reality of the global order. This reality is often measured through the identity of the American cultural lens which is demonstrated worldwide. This attitude by Koencaraningrat is called "attitude of lack of self- 
Volume 1 (3) 2020

E-ISSN: 2723-6919 P-ISSN:2746-0827

respect" which leads people to think that the products of other people or other nations are of higher quality and worth (Febiyanti et al, 2020). This negative attitude is also addressed by the government. For example Permenaker No. 12 of 2013 which requires foreign workers to master the Indonesian language, was revised by Permenaker No. 16 of 2015 so that foreigners working in Indonesia do not need to master Indonesian. Another thing that supports other negative things about the struggle for Indonesian as a world language is Permenristekdikti No. 20 of 2017 which requires that international journals published in Indonesia must be in official languages (UN Arabic, English, French, Russian, Spanish, and Chinese).

Other negative attitudes are: (1) Most Indonesian people do not use the correct language, because they do not master the Indonesian language well. Even though the correct use of Indonesian is a reflection of a positive attitude that creates a sense of pride in the language. This attitude supports the development of the Indonesian language as the identity of the Indonesian nation and is a reflection of a clear, logical, and orderly mind. Someone uses language chaotically, of course, describes a chaotic way of thinking too. On the other hand, if someone uses language regularly, clearly, and systematically, that person's way of thinking is orderly and clear as well. Therefore, every Indonesian should use the Indonesian language correctly so that their thoughts are orderly and easily understood by others.

These errors occur everywhere and are carried out systematically and consistently so that there are misunderstandings, errors that are not realized by language users because the user is following wrong habits, and these habits are never corrected. These mistakes are understandable by society and are often used so that they are considered correct.

Other negative attitudes are (2) mistakes due to the lack of mastery of the Indonesian language system and confusion of thought, which finally appears in the language used. This is of course worrying because the right things go wrong, the wrong things become right. If it becomes the character of the nation, then we will become a nation that is not only "always wrong" but a nation that "always lose".

The negative attitude (3) is that in the academic environment, oral language does not have rules, so that when testing Indonesian language proficiency for speaking sessions = is still weak, even though in the BIPA curriculum this is very important. In South Korea, the institution that tests language proficiency is not the Language Agency or diplomatic corps / Indonesian embassy in that country, or institutions originating from Indonesia, but HUFS (a university that specializes in studying foreign languages. This condition is against the US (TOEIC, TOEFL), German (Goethe-Z Certificate), Chinese (HSK), Japan (JLPT), Korea (TOPIK), and many other countries that already have their language proficiency test.

\section{Conclusion}

Carrying native Indonesian speakers in ASEAN has a valid and reliable tendency. This is supported by the nuances of the internal and external linguistic factors that influence the trend phenomenon. Presidential Regulation no. 63 of 2019, the consistency needs to be realized and implemented, but there is no sanction from the Presidential Regulation, so it is feared that it will become an infertile Perpres. The result can be fatal because of the existence of Presidential Regulation no. 63 of 2019, until today as an unsanctioned instrument. Even though the Indonesian language can maintain the authority of the Indonesian State. Thus the recommendation that can be carried out from this research activity is the revision of Indonesian 
Volume 1 (3) 2020

E-ISSN: 2723-6919 P-ISSN:2746-0827

politics in 2021 by prioritizing various internal factors of language, both formal and non-formal (millennial social language), as well as various external factors.

\section{E. Acknowledgement}

I would like to express my special thanks and gratitude to Rector Universitas Bengkulu and Dean of FKIP Universitas Bengkulu who gave me the support to do this wonderful project. Secondly, I would also like to thank my friends in Universitas Bengkulu who helped me a lot in finalizing this project within the limited time frame.

\section{References}

Antaranews.com. (2020). UNESCO Tetapkan Pantun Sebagai Warisan Budaya Dunia Tak Benda [Establish Rhymes As Intangible World Cultural Heritage]. London: https://www.antaranews.com/berita/1901568/unesco.

Arka, I. W. (2020). Symposium on Language, Health, \&Wellbeing. Canberra: chl.anu.edu.au.

Arka, I. W. (2020). The Language Documentation Quartet. Shassion on Linguistics. Webinar, Linguistic Documentation.

Baayen, K. D. (2020). Affix substitution in Indonesia and its impact for discriminative learning. UCREL Corpus research Seminar. Lancaster Univ: University Centre for Computer Corpus Research on Language.

BaBe. (2020). Ratusan Profesor Rekomendasikan Bahasa Indonesia Jadi Bahasa Ilmiah International [Hundreds of Professors Recommend Indonesian Language to Become International Scientific Language]. Jakarta: http://share.babe.news/s/scmfNTpQvR.

Badan Pengembangan dan Pembinaan Bahasa, K. (2020). peluncuran-pedoman-perubahanperilaku-protokol-kesehatan-3m-dalam-77-bahasa-daerah.

Jakarta: https://balaibahasasadiy.kemdikbud.go.id/laman/index.php/informasi/berita/item/182.

Bagus, R. G. (2016). Negara Bagian di Australia ini Gunakan Bahasa Indonesia Sebagai Bahasa Asing Utama [This state in Australia uses Indonesian as its main foreign language]. https://www.goodnewsfromindonesia.id/2016/10/13/negara-bagian-di australia-ini-gunakan-bahasa-indonesia-sebagai-bahasa-asing-utama.

Bahasa, B. P. (2018). Program Rutin [Routine Program]. Jakarta: Badan Pembinaan dan Pengembangan Bahasa.

Bahtiar, A. (2020). Bahasa Indonesia, Menjadi Bahasa Dunia [Indonesian Language, Becoming the World Language]. Solo, Jawa Tengah, Indonesia.

balaibahasadiy.kemendikbud.go.id. (2020). Peluncuran Pedoman Perubahan Perilaku Protokol Kesehatan 3M dalam 77 Bahasa Daerah [Launch of 3M Health Protocol's Code of Conduct Change in 77 Local Languages]. Jakarta: Badan Pengembangan dan Pembinaan Bahasa.

Chomsky, N. (2006). Language \& Mind, Tird Edition. Cambridge: w.w.w cambridge.org/9780521858199. 
Chomsky, N. (2006). Language and Mind. Cambridge: Cambridge University Press.

CNN. (2020). Diplomasi Budaya Dan Bahasa Di Belanda [Cultural and Language Diplomacy in the Netherlands]. Jakarta: CNN.

Comri, B. (2009). Languange Primary In The Word, The second Edition. London: RoutledgeTaylor \& Francis e-library.

Crosthwaite, P. (2020). Trainee EFL teacher DDL lesson planning: Improving corpus-focused TPACK in Indonesia. UCRELCRS-2020. University of Queensland Australia.

Dahlan, M. A. (2000). Bahasa Indonesia dalam Era Globalisasi, Bahasa Indonesia dalam Kehidupan Bermasyarakat, Berbangsa, dan Bernegara: Perannya Menghadapi Globalisasi [Indonesian in the Age of Globalization, Indonesian in the Life of a Society, Nation and State: Its Role in Facing Globalization]. Pusat Pembinaan Dan Pengembangan Bahasa Departemen Pendidikan Nasional, 1975. Politik Bahasa Nasional.

Febiyanti, H., Ariana, S., \& Zainal, R. I. (2020). Functional Instructor Needs for Application of General Services Agency. International Journal of Progressive Sciences and Technologies, 23(1), 347-352.

dewara.com. 10 bahasa paling banyak penuturnya di dunia [The 10 most spoken languages in the world].

https://www.kompas.com/skola/read/2020/01/12. (2020). Kondisi-geografi-asia-tenggaraluas-dan-bentangnya?page=all. Jakarta: kompas.com .

Hyun, P. J. (2020). Potensi Dan Tantangan Bahasa Indonesia Menuju Bahasa Internasional (Potentials and Challenges of Indonesian Language Towards an International Language). Sosioteknologi: ITB Bandung 14(1).

https://www.liputan6.com (2020). 6-negara-asia-tenggara-dengan-militer-terkuat-versi-gfpri-nomor-berapa. https://www.liputan6.com/global/read 3930345.

Indonesia, K. R. (2020). Program Merdeka Belajar dan Kampus Merdeka Belajar [Independent Learning Program and Independent Learning Campus]. Jakarta: Kemendikbud.

Indonesia, P. P. (1928). Sumpah Pemuda [Youth Pledge].

Langgeng, S. M. I. (2012). analisis-tantangan-bahasa-indonesia-menjadi-bahasainternasional. -: https://blog.ub.ac.id/langgeng/2012/05/18.

M.Ridwan. (2020). Virtual Zoom: Visiting Proffesor 2 UMM.

Malsasa. (2012). Apa Arti Bahasa Menunjukkan Bangsa [What the Meaning of Language Shows Nation]. Jakarta: Indonesia.

Mayani, L. A. (2020). Peluang Pengajaran BIPA [BIPA Teaching Opportunities]. Konferensi BIPA 2020. 
Mayani, L. A. (2020). Peluang Pengembangan BIPA di Asia Tenggara [BIPA Development Opportunities in Southeast Asia]. Southeast asian Minister of Education Organization (SEAMEO), \& Regional Center for. Singapura: SEAMEO \& SEAQIL.

Nuigini, D. B. (2020). Bahasa Indonesia Bahasa Asing Kedua. Jakarta: Kompas TV.

Purwo, B. K. (2020). Penelitian Linguistik Mileneal [Mileneal Linguistic Research]. Jakarta: Masyarakat Linguistik Indonesia Kelas Daring.

RAJEG, G. P. (2020). Usage-based perspective on the meaning-preserving hypothesis in voice alternation: Corpus linguistic and experimental studies in Indonesian. UCREL Corpus Research Seminar. Lancaster University: Lancaster University Press.

Ramadhan, B. (2016). Negara Bagian di Australia ini Gunakan Bahasa Indonesia sebagai Bahasa Asing Utama [This state in Australia uses Indonesian as the main foreign language]. google: https://goodnewsfromindonesia.id/2016/10/13.

Rambu, C. G. (2016). The Use of Indonesian Language In Indonesian Defense Diplomacy Toward ASEAN Countries. Jurnal Pertahanan, vol 6, no.1, 248.

Ridwan, M. (2020). Program Visiting Profesor Virtual. Jawa Timur, Indonesia.

Steinhauer, H. (1994). Situasi Bahasa \& Linguistik Indonesia, Prospek dan Kemungkinan [Indonesian Language \& Linguistic Situation, Prospects and Possibilities]. Bijdragen Tot de Taal-, Land-en Volkenkunden, 755-784.

Sudaryanto. (2017). Menguak Tiga Fase Kehidupan Bahasa: Fungsi Hakikinya, Pengelola Ilmunya, Keterkaitan dengan Budaya [Unraveling the Three Phases of Language Life: Its Essential Functions, Knowledge Managers, Cultural Connections]. Jogyakarta: Sanata Dharma University Press.

Sugono, D. (2017). Bahasa Indonesia Menuju Bahasa Internasional [Indonesian to International Language]. Fon : Jurnal Pendidikan Bahasa \& Sastra Indonesia, Program Studi Pendidiikan Bahasa \& Sastra Indonesia FKIP Universitas Kuningan, 11(2).

Suprianyanto. (2016). Bahasa Indonesia Menuju Bahasa Internasional [Indonesian to International Language]. Jakarta: Badan Bahasa. kemendikbud.go.id.

tempo.co/read/1307583/bps-proyeksi-jumlah-penduduk-indonesia-319-juta-jiwa-pada2045/full\&view=ok, b. (2020, November Wednesday, 26 November 2020). Total Population of Indonesia. Jakarta, DKI, Indonesia.

TV, C. (2020). Bahasa dan Budaya Indonesia di Belanda [Indonesian Language and Culture in the Netherlands]. Media Sosial Televisi: CNN TV.

TV, K. (2020). Bahasa Indonesia Di Papua Nuigini [Indonesian in Papua New Guinea]. Media Sosial televisi: Kompas TV.

TV, M. (2020). Bahasa Indonesia di Papua nuigini [Indonesian in Papua New Guinea]. Metro TV. 
Journal of Social Work and Science Education

Volume 1 (3) 2020

E-ISSN: 2723-6919 P-ISSN:2746-0827

University, B. (2020, November Kamis). Kosa Kata Pandemi [Pandemic Vocabulary].

Retrieved 2020 Thursday, 2020, from Binus University: binus.ac.id/malang/2020/pandemi-koronavarius-memperkaya-khazanah-istilah-dankosakata-bahasa-indonesia

Wardhana, D. E. (2018). Peradaban Komunikasi Berbasis Kearifan Nasional dan Kearifan Lokal Pada Masyarakat Multi Budaya [Communication Civilization Based on National Wisdom and Local Wisdom in a Multi-Cultural Society]. Kongres Internasional Masyarakat Linguistik Indonesia (KIMLI) 2018 (pp. 30-36). Manokwari: Masyarakat Linguistik Indonesia.

Widodo, H. P. (2020). Journal International Students Agency and Identity. virtual: Komunitas Medan KUMMITE.

Yansen. (2019). Program UPT KSLI Universitas Bengkulu [Program UPT KSLI Bengkulu University]. Bengkulu: UPT KSLI Universitas Bengkulu. 